\title{
Chemical Constituent from Roots of Garcinia Mangostana (Linn.)
}

\author{
Sheikh Ahmad Izaddin Sheikh Mohd Ghazali (Corresponding author) \\ Faculty of Applied Sciences, Universiti Teknologi MARA \\ 72000 Kuala Pilah, Negeri Sembilan, Malaysia
}

Tel: 60-9-483-2100Ｅ-mail: sheikhahmadizaddin@ns.uitm.edu.my

\author{
Gwendoline Ee Cheng Lian \\ Department of Chemistry, Universiti Putra Malaysia \\ 43400 Serdang, Selangor, Malaysia \\ E-mail: gwen@fsas.upm.edu.my \\ Kay Dora Abd Ghani \\ Faculty of Civil Engineering, Universiti Teknologi MARA \\ 02600 Arau, Perlis, Malaysia \\ E-mail: kaydora@perlis.uitm.edu.my
}

\begin{abstract}
Novel extraction studies on Garcinia mangostana roots was chemically investigated. Detail phytochemical studies on the roots of Garcinia mangostana have resulted in the isolation of six compounds. The structures of these compounds were elucidated using spectroscopic experiments namely NMR, IR, UV and MS. The root bark of Garcinia mangostana furnished six xanthones, $\alpha$-mangostin (1), $\beta$-mangostin (2), $\gamma$-mangostin (3), garcinone-D (4), mangostanol (5), and gartanin (6).
\end{abstract}

Keywords: Garcinia mangostana, Xanthones, Roots

\section{Introduction}

Malaysia is known as one of the 12 mega diversity countries that are rich with phanerogamic and cryptogamic flora. In total, the biodiversity of Malaysia's plant resources offer some 15000 species of higher plants. From this, 1300 are said to be medicinal but only about a hundred have been investigated. A majority of plants have not been evaluated for their potentials (Goh, 1988). Garcinia is a large genus of polygamous trees or shrubs, distributed in Tropical Asia, Africa, and Polynesia. It consists of 180 species, out of which about 30 species are found in India. It is reputedly named after a French explorer, Jacques Garcin (1673-1751). In Europe and North America, the most recognizable member of this family is the popular herb St. John's wort. Mangosteen is one of the most widely recognized tropical fruits and has universal appeal because of its quality in color, shape and flavor. The mangosteen tree is a small, broad-leaved and evergreen. It has a short upright or pyramidal form, reaching a spread of 20 to 30 feet in diameter. The central trunk is upright and is branched symmetrically. The leaves are elliptical in form and vary in size from 6 to 10 inches in length and 3 to 6 inches in width. Leaves are thick and leathery. Flowers are greenish-white and are borne single or in pairs, usually at the end of the branches. The fruit has a smooth skin and a thick rind, which encloses as many as 5 to 7 fleshy segments, in which the seeds are imbedded. The fruit is in the form of a small tangerine, flattened a little above and below, and changes from clear green to reddish-purple when completely ripe. Mangosteen is also used as a pharmaceutical.

\section{Research Methodology}

The root material was collected from Alor Gajah, Melaka. The finely powdered roots $(\approx 1.0 \mathrm{~kg})$ was extracted sequentially with distilled hexane, chloroform and acetone. The crude extracts were filtered and after removal of the solvents by rotary evaporator to yield dark residues weighing $11.5,35.3$, and $63.7 \mathrm{~g}$ respectively. Column chromatography on the crude hexane extract yielded two xanthones compounds, $\alpha$-mangostin (1) and $\beta$-mangostin (2). 
The chloroform extract gave two pure compunds namely $\gamma$-mangostin (3) and garcinone D (4) while the crude acetone extract provided gatanin (5) and mangostanol (6).

\section{Results and discussion}

$\alpha$-mangostin (1) (4 mg) was obtained as a yellow amorphous powder with melting point $180-182{ }^{\circ} \mathrm{C}$ (Yates, 1980). The EIMS spectrum showed the presence of a molecular ion peak at $\mathrm{m} / \mathrm{z} 410$ which validated a molecular formula $\mathrm{C}_{24} \mathrm{H}_{26} \mathrm{O}_{6}$. The IR spectrum gave an absorption at $3422 \mathrm{~cm}^{-1}$ indicating the presence of a phenolic group. Meanwhile a strong absorption at $\delta 1642 \mathrm{~cm}^{-1}$ and $1284 \mathrm{~cm}^{-1}$ indicated the presence af a chelated carbonyl group in the middle ring and a methoxy group. Absorptions at 214.5, 243.0 and $317.0 \mathrm{~nm}$ in the UV are typical of a xanthone. The ${ }^{1} \mathrm{H}-\mathrm{NMR}$ spectrum of (1) showed singlet signals at $\delta 6.25$ and $\delta 6.72$ which were assigned to the two isolated aromatic protons at positions C-4 and C-5 respectively. Meanwhile the presence of 3-methylbut-2-enyl groups was confirmed by the following characteristic signals. Two doublet signals at $\delta 3.37(J=7.3 \mathrm{~Hz})$ and $\delta 4.10(J=7.3 \mathrm{~Hz})$ were attributed to the benzylic methylene groups at $\mathrm{C}-11$ and $\mathrm{C}-16$. A triplet at $\delta 5.26$ which intergrated to two protons were due the vinylic protons at $\mathrm{C}-12$ and $\mathrm{C}-17$. Meanwhile, four singlet signals at $\delta 1.71, \delta 1.82, \delta 1.68$, and $\delta 1.84$ were assigned to $\mathrm{H}-14, \mathrm{H}-15, \mathrm{H}-19$ and $\mathrm{H}-20$, respectively. The COSY spectrum showed the couplings between $\mathrm{H}-11$ and $\mathrm{H}-12$ as well as between $\mathrm{H}-12$ and $\mathrm{H}-14$ and $\mathrm{H}-15$ hence confirming the presence of a prenyl moiety in (1). From the ${ }^{13} \mathrm{C}$ analysis gave a total of twenty-four carbons which confirmed to a molecular formula $\mathrm{C}_{24} \mathrm{H}_{26} \mathrm{O}_{6}$. The signal that was observed at $\delta 6.12$ was assigned to the methoxy carbon. All protonated carbons of $\alpha$-mangostin (1) were assigned by the HSQC analysis. In the HMBC analysis of $\alpha$-mangostin (1) the position for two prenyl moieties were confirmed to be at C-2 and C-8 positions. This is shown by the correlations between the methylene proton signals of the prenyl moiety at $\delta 4.10(\mathrm{H}-11)$ with the carbon signals at $\delta 137.2(\mathrm{C}-8)$, while H-16 signals showed correlation with the carbon signals at $\delta$ 109.7. Other than that, the position for the methoxy group was confirmed to be at C-7 ( $\delta$ 142.7). The comparison data are shown in Table 1. $\alpha$-mangostin (1) was therefore identified as $\alpha$-mangostin as shown in Figure 1 and the spectral data are summarized in Table 1.

$\beta$-mangostin (2) (3 mg) was obtained from the crude choloroform extract of roots of Garcinia mangostana L. It was isolated as pale yellow crystal with a melting point $162-163{ }^{\circ} \mathrm{C}$ (Yates, 1980). The EIMS spectrum of $\beta$-mangostin (2) indicatied the molecular ion peak at $\mathrm{m} / \mathrm{z} 424$ which corresponds to a molecular formula, $\mathrm{C}_{24} \mathrm{H}_{28} \mathrm{O}_{6}$. The IR spectrum showed absorptions at $1648 \mathrm{~cm}^{-1}$ and $3400 \mathrm{~cm}^{-1}$ due to a highly chelated carbonyl and the phenolic hydroxyl. The UV absorption at 213.5, 245.0, 259.0, and $315.5 \mathrm{~nm}$ is typical of a 1,3,6,7 tetraoxygenated xanthone. The ${ }^{1} \mathrm{H}$ NMR spectrum showed the presence of one chelated hydroxyl group at $\delta 13.35$. The presence of two prenyl groups was confirmed by the following characteristic signals: two doublets at $\delta 3.28(J=7.2 \mathrm{~Hz})$ and $\delta 4.00(J=7.2 \mathrm{~Hz})$ were assigned to the methylene groups at $\mathrm{C}-16$ and $\mathrm{C}-11$; a triplet at $\delta 5.18(\mathrm{~J}=7.2 \mathrm{~Hz})$ and $\delta 5.17(\mathrm{~J}=7.2 \mathrm{~Hz})$ was due to the vinylic proton at $\mathrm{C}-12$ and $\mathrm{C}-17$, while four singlet at $\delta 1.61, \delta 1.72, \delta 1.62$, and $\delta 1.75$ were attributed to H-14, H-15, H-19 and H-20, respectively. Lastly, the two remaining singlet signals at $\delta 3.73$ and $\delta 3.82$ in the ${ }^{1} \mathrm{H}$ NMR spectrum were assigned to the two methoxyl groups in the compound. The COSY spectrum showed correlations between the olefinic proton of C-12 and the benzylic proton of $\mathrm{C}-11$, and the geminal dimethyl group of $\mathrm{C}-14$ and $\mathrm{C}-15$. The same correlations as above are also observed for the other 3-methylbut-2-enyl group.The ${ }^{13} \mathrm{C}$ NMR analysis gave a total of twenty five carbons. The very downfield signal at $\delta 181.9$ was assigned to the carbonyl group in the middle ring. The methoxy carbon signals were observed at $\delta 55.8$ and $\delta 62.1$. All protonated carbons were assigned by HSQC analysis. In the HMBC spectrum, the methylene proton signal of the 3, 3-dimethylallyl substituent at $84.10(\mathrm{H}-11)$ showed long range correlations with the carbon signals at $\delta 137.0(\mathrm{C}-8)$, while the $\mathrm{H}-16$ signal correlated with $\delta 111.4(\mathrm{C}-2)$ thus comfirming the location of the 3,3-dimethylallyl substituent to be at $\mathrm{C}-8$ and $\mathrm{C}-2$. The methoxy groups of $\beta$-mangostin (2) were assigned to $\mathrm{C}-3$ ( $\delta 163.4)$ and C-7 ( $\delta 142.5)$. Compound (2) was therefore, identified as $\beta$-mangostin (Figure 2) and the spectral data are summarized in Table 2.

$\gamma$-mangostin (3) (3) (8 mg) was obtained as pale yellow crystals with a melting point of $200-202{ }^{\circ} \mathrm{C}$. The EIMS spectrum showed the presence of a molecular ion peak at $\mathrm{m} / \mathrm{z} 396$. The IR spectrum showed an absorption at $3300 \mathrm{~cm}^{-1}$ and $1640 \mathrm{~cm}^{-1}$ which were due to the chelated carbonyl function and phenolic hydroxyl. Meanwhile the UV absorptions at $239.5,262.5,313.5$ and $377.0 \mathrm{~nm}$ indicated it to be a hydroxyl xanthoneThe ${ }^{1} \mathrm{H}-\mathrm{NMR}$ analysis showed that two singlet signals that appeared at $\delta 6.15$ and $\delta 6.60$ belong to the aromatic protons at $\mathrm{H}-4$ and $\mathrm{H}-5$ respectively. Meanwhile the presence of two prenyl moiety was confirmed by the following characteristic. Two doublets at $\delta 3.23(\mathrm{~J}=6.8 \mathrm{~Hz})$ and $\delta 4.05(J=6.4 \mathrm{~Hz})$ were assigned to the methylene groups at $\mathrm{C}-11$ and $\mathrm{C}-16$, a triplet at $\delta 5.22(J=6.4 \mathrm{~Hz}, 6.8 \mathrm{~Hz})$ was due to the vinylic proton at $\mathrm{C}-12$ and $\mathrm{C}-17$, while four singlets at $\delta 1.80, \delta 1.63, \delta 1.63$ and $\delta 1.75$ were attributed to H-14, H-15, H-19 and H-20, respectively.The COSY spectrum showed clearly the correlation for benzylic methylene proton (H-11) and vinylic proton (H-12) thus suggesting the presence of a prenyl moiety in (3). The same correlation pattern also has been shown by another prenyl unit in the COSY analysis in which $\mathrm{H}-16$ correlated to H-17.The ${ }^{13} \mathrm{C}$-NMR spectrum gave a total of 23 carbon resonances which corresponds to a molecular formula $\mathrm{C}_{23} \mathrm{H}_{24} \mathrm{O}_{6}$. The downfield signal at $\delta 183.4$ was due to the carbonyl group of (3). Other protonated carbons of (3) were assigned by HSQC analysis. The DEPT experiment showed that (3) consists of four methines, two methylenes, four methyls and 
thirteen quarternary carbons.Conclusive proof for the substitution pattern of (3) was the same from the HMBC analysis. In the HMBC analysis the methylene proton signal of the 3-methylbut-2-enyl at $\delta 4.05$ (H-11) showed long range correlation with the carbon signals at $\delta 129.4(\mathrm{C}-8)$, thus suggesting the location of the 3-methylbut-2-enyl to be at C-8. Meanwhile another prenyl unit was confirmed to be at $\mathrm{C}-2$ when the methylene proton at $\delta 3.23(\mathrm{H}-16)$ correlated with the carbon signals at $\delta 111.0(\mathrm{C}-2)$.Compound (3) was therefore identified as $\gamma$-mangostin as shown in Figure 3 and the comparison of spectral data with literature value (Ishigoru et al., 1992) are shown in Table 3.

garcinone-D (4) $(5 \mathrm{mg})$ was obtained as brownish crystals with a melting point of $150-154{ }^{\circ} \mathrm{C}$. This compound reacted positively with $\mathrm{FeCl}_{3}$. The EIMS spectrum showed the $\left[\mathrm{M}^{+}\right]$at 428 which validated to the molecular formula $\mathrm{C}_{24} \mathrm{H}_{28} \mathrm{O}_{7}$. The IR spectrum showed absorptions at 3406 and $1640 \mathrm{~cm}^{-1}$ which suggested the presence of a chelated hydroxyl and conjugated carbonyl group of (4), respectively. Meanwhile UV spectrum of (4) showed absorptions at 244.5 and 318.0 $\mathrm{nm}$ which are characteristic of an oxygenated xanthone.The ${ }^{1} \mathrm{H}-\mathrm{NMR}$ analysis showed one chelated $\mathrm{OH}$ at $\delta 13.81$ which is attached to $\mathrm{C}-1$. The occurance of prenyl moiety was confirmed by the two singlets at $\delta 1.76(3 \mathrm{H}, \mathrm{s}, \mathrm{H}-19)$ and $\delta 1.62(3 \mathrm{H}, \mathrm{s}, \mathrm{H}-20)$, a doublet at $\delta 3.32(2 \mathrm{H}, J=7.3 \mathrm{~Hz}, \mathrm{H}-16)$ and a triplet at $\delta 5.26(1 \mathrm{H}, J=7.3 \mathrm{~Hz}, \mathrm{H}-17)$. Meanwhile the singlet signal which resonates at $\delta 3.83$ was assigned to the methoxyl group at C-7. Nevertheless, the presence of 3-hydroxy-3-methylbutanyl moiety was confirmed by the following characteristic signals: a singlet at $\delta 1.29$ which integrated to six protons were due to methyl groups at C-14 and C-15. Two multiplets at $\delta 1.74$ and $\delta 3.46$ was attributed to $\mathrm{H}-12$ and $\mathrm{H}-11$, respectively. The aromatic proton singlets at $\delta 6.38$ and $\delta 6.79$ in the ${ }^{1} \mathrm{H}-\mathrm{NMR}$ spectrum of (4) were assigned to H-4 and H-5. The COSY spectrum showed that correlations between the olefinic proton of C-17 and the benzylic proton of $\mathrm{C}-16$, and the geminal dimethyl groups at C-19 and C-20. This confirmed the presence of a prenyl moiety in (4). All protonated carbons of (4) were assigned by the HSQC analysis. The ${ }^{13} \mathrm{C}-\mathrm{NMR}$ experiment showed that compound (4) gave a total of 24 carbons. Meanwhile from the DEPT spectrum three methines, three methylenes, five methyls and thirteen quartenary carbon signals were observed, hence, supporting the structure of (4).In the heteronuclear multiple bond connectivity (HMBC) spectrum, the methoxy group of (93) was found to be at C-7. The location of the prenyl moiety was suggested to be at C-2 when the methylene proton signal of the prenyl side chain at $\delta$ 3.32 showed long range correlation with the carbon signl at $\delta 140.0(\mathrm{C}-8)$. Comparison of these data with those reported earlier by Bennet et al., (1993). Figure 4 and Table 4 showed that (93) was identical to garcinone D.

Mangostanol (5) (2 mg) was isolated as yellowlish crystal with a melting point of $164-166^{\circ} \mathrm{C}$. The EIMS spectrum showed a molecular ion peak at 396 which corresponded to the molecular formula $\mathrm{C}_{23} \mathrm{H}_{24} \mathrm{O}_{6}$. The IR spectrum showed strong absorptions at $3200 \mathrm{~cm}^{-1}$ and $1610 \mathrm{~cm}^{-1}$ which are due to a hydroxyl group and carbonyl group in (5). The UV absorption at 325 and $249 \mathrm{~nm}$ confirmed the characteristic nature of xanthone. The ${ }^{1} \mathrm{H}$ NMR spectrum of (5) showed one chelated hydroxyl group which was observed at $\delta 12.34(1 \mathrm{H}, \mathrm{s}, \mathrm{OH}-1)$. Two pair of doublets which observed at $\delta$ $7.22(1 \mathrm{H}, J=9.2 \mathrm{~Hz})$ and $\delta 6.66(1 \mathrm{H}, J=9.2 \mathrm{~Hz})$ were assigned to $\mathrm{H}-6$ and $\mathrm{H}-7$, respectively. Another singlet signal at $\delta$ 11.26 was due to another hydroxyl group at position C-8. The existence of two prenyl moieties in (5) was confirmed by the following characteristic: two doublets at $\delta 3.45(J=8.2 \mathrm{~Hz})$ and $\delta 3.51(J=6.4 \mathrm{~Hz})$ were attributed to the methylene group at $\mathrm{C}-11$ and $\mathrm{C}-16$, a multiplet at $\delta 5.26(J=7.3 \mathrm{~Hz})$ was due to the vinylic proton at $\mathrm{C}-12$ and $\mathrm{C}-17$, while four singlets at $\delta 1.79, \delta 1.86, \delta 1.86$ and $\delta 1.75$ were assigned $\mathrm{H}-14, \mathrm{H}-15, \mathrm{H}-19$ and $\mathrm{H}-20$, respectively. The ${ }^{13} \mathrm{C}$ NMR spectrum showed a total of 23 carbons which validated the molecular formula. The very downfield signal at $\delta 184.8$ was due to a carbonyl group in (5). The COSY spectrum showed clearly a correlation between H-6 and H-7. Meanwhile all protonated carbons in (5) were assigned by using HSQC analysis. In the HMBC spectrum showed the prenyl moiety was confirmed at position number two while the methylene proton at $\delta 3.45(\mathrm{H}-11)$ showed long range correlation with $\delta 109.6(\mathrm{C}-2)$. Another prenyl group in (5) was assigned at position C-4 when the methylene proton at $\delta 3.51(\mathrm{H}-16)$ gave correlation to $\delta 105.9$ (C-4) as shown in Figure 5.The assignments of (5) along with spectral data are summarized in Table 5.

Gartanin (6) (6 mg) was isolated as a yellow gum and gave a positive result when tested with alcoholic $\mathrm{FeCl}_{3}$. The EI-MS spectrum showed $\left[\mathrm{M}^{+}\right]$at $\mathrm{m} / \mathrm{z} 426$ which corresponds to the molecular formula $\mathrm{C}_{24} \mathrm{H}_{26} \mathrm{O}_{7}$. The IR spectrum indicated the presence of a chelated hydroxyl and conjugated carbonyl group at 3406 and $1600 \mathrm{~cm}^{-1}$. Meanwhile the ultra violet analysis gave absorption at 205.0, 244.0 and $306.5 \mathrm{~nm}$. The ${ }^{1} \mathrm{H}-\mathrm{NMR}$ spectrum showed two aromatic proton signals appearing at $\delta 6.30$ and $\delta 6.62$ which were assigned for H-10 and H-12. A single methoxy resonance occurred at $\delta 3.70$. The presence of a prenyl moiety was confirmed by the following characteristic: a doublet signal at $\delta 4.00(J=7.3$ $\mathrm{Hz})$ was assigned to a benzylic methylene group at C-1'. Meanwhile, a triplet at $\delta 5.24(J=7.3 \mathrm{~Hz})$ was due to the vinylic proton at C-2'. Two singlet signals that resonate at $\delta 1.77$ and $\delta 1.62$ were attributed to H-4' and H-5'. The remaining proton signals were due to the presence of 2,2-dimethyl-chroman-3-ol unit. The unit was shown by the signals at $\delta 3.74(1 \mathrm{H}$, dd, $J=5.5 \mathrm{~Hz}, \mathrm{H}-3), \delta 2.88(1 \mathrm{H}, \mathrm{dd}, J=5.5,17.4 \mathrm{~Hz}, \mathrm{H}-4), \delta 2.52(1 \mathrm{H}, \mathrm{dd}, J=7.3,17.4 \mathrm{~Hz}, \mathrm{H}-4), \delta$ $1.30\left(3 \mathrm{H}, \mathrm{s}, 2-\mathrm{CH}_{3}\right)$ and $\delta 1.25\left(3 \mathrm{H}, \mathrm{s}, 2-\mathrm{CH}_{3}\right)$. The COSY spectrum showed clearly that $\mathrm{H}-3$ and $\mathrm{H}-4$ were coupled to each other. On the other hand, the presence of a prenyl moiety of (6) was confirmed when the benzylic methylene proton (H-1') and the vinylic proton (H-2') showed their correlation to each other.The ${ }^{13} \mathrm{C}-\mathrm{NMR}$ analysis gave a total of 24 carbons. The very downfield signal at $\delta 178.9$ was assigned to the carbonyl group of (6). All protonated carbons of (6) 
were identified by the HSQC analysis). In the DEPT spectrum four methines, two methylenes, five methyls and thirteen quartenary carbon signals were observed hence supporting the structure of (6).Conclusive proof for the substitution pattern of (6) was shown by the correlation peaks in the HMBC spectra. In the HMBC spectrum the methoxy group was assigned to be at $\delta 144.8(\mathrm{C}-8)$. The correlation of the benzylic methylene proton $\mathrm{H}-1$ ' to C-6a $(\delta 114.7), \mathrm{C}-8(\delta 144.7)$ and C-7 ( $\delta$ 138.3) suggested the location of the prenyl moiety to be at C-7. Other than that, the geminal methyl signals at $\delta 1.30$ and $\delta 1.41$ coupled to each other and two carbinol carbon signals at $\delta 69.6(\mathrm{C}-3)$ and $\delta 79.5(\mathrm{C}-2)$. All the above data are in good agreement with previous report by Chairungsriled et al., (1996). Compound (6) was therefore confirmed to be mangostanol as shown in Figure 6 and the spectral data are summarized in Table 6.

\section{Conclusion}

Investigations on rootbark of Garcinia mangostana L. have afforded six xanthones $\alpha$-mangostin (1), $\beta$-mangostin (2), $\gamma$-mangostin (3), garcinone-D (4), mangostanol (5) and gartanin (6). Up to now, research has only been carried out on the fruit hull and the stem bark of this plant. There have been no studies yet on the root bark of Garcinia mangostana.

\section{References}

Bennett, G.J. and Lee, H.H. (1989). Xanthones from Guttiferae. Phytochemistry, 28 (4): 968-998.

Chairungsrilerd, N., Takeuchi, K., Ohizumi, Y., Nozoe, S. and Ohta, T. (1996). Mangostanol, a prenyl xanthone from Garcinia mangostana. Phytochemistry. 43 (5): 1099-1102.

Goh, S.H. (1988). Chemical and pharmacological constituent in traditional medicine. Proceedings:Malasysian traditional medicine, ed. E. Soepadmo et al., pp 7-26. Kuala Lumpur: Institute of Advance Studies, University Malaya.

Ishiguro Kyoko, Hisae Fukumoto, Mariko Nakajiwa, and Koichiro Isoi, (1993). Xanthones in cell suspension cultures of Hypericum Paturun. Phytochemistry, 33 (44): 839-840.

Sen, A.K., Sarkar, K. K., Mazumder, P. C., Banerji, N., Uusvuori, R. and Hase, T. A. (1982). The structures of Garcinones A, B and C: Three new xanthones fom Garcinia mangostana. Phytochemistry, 21 (7): 1747-1750.

Yates, P. and Stout, G. H., (1980). The structure of mangostin. Journal of American Chemistry Society, 80:1670-1691.

Table 1.

\begin{tabular}{|c|c|c|c|}
\hline Position & $\delta \mathbf{H}$ & $\delta C^{*}$ & $\delta \mathrm{C}$ \\
\hline 1 & $13.72(1 \mathrm{H}, \mathrm{s}, \mathrm{OH})$ & 160.6 & 160.2 \\
\hline 2 & - & 108.4 & 109.7 \\
\hline 3 & - & 161.6 & 161.6 \\
\hline 4 & $6.25(1 \mathrm{H}, \mathrm{s})$ & 93.3 & 92.4 \\
\hline $4 \mathrm{a}$ & - & 154.5 & 154.8 \\
\hline 5 & $6.72(1 \mathrm{H}, \mathrm{s})$ & 101.5 & 101.6 \\
\hline 6 & - & 155.7 & 155.4 \\
\hline 7 & - & 142.5 & 142.7 \\
\hline 8 & - & 137.0 & 137.2 \\
\hline $8 \mathrm{a}$ & - & 112.2 & 111.7 \\
\hline 9 & - & 182.03 & 181.8 \\
\hline $9 \mathrm{a}$ & - & 103.6 & 103.1 \\
\hline $10 \mathrm{a}$ & - & 155.0 & 155.2 \\
\hline 11 & $4.10(2 \mathrm{H}, \mathrm{d}, J=7.3 \mathrm{~Hz})$ & 21.44 & 26.3 \\
\hline 12 & $5.26(1 \mathrm{H}, \mathrm{t}, J=7.3 \mathrm{~Hz})$ & 121.4 & 122.1 \\
\hline 13 & - & 132.1 & 131.7 \\
\hline 14 & $1.71(3 \mathrm{H}, \mathrm{s})$ & 25.8 & 25.7 \\
\hline 15 & $1.82(3 \mathrm{H}, \mathrm{s})$ & 17.9 & 17.7 \\
\hline 16 & $3.37(2 \mathrm{H}, \mathrm{d}, J=7.3 \mathrm{~Hz})$ & 26.6 & 21.3 \\
\hline 17 & $5.26(1 \mathrm{H}, \mathrm{t}, J=7.3 \mathrm{~Hz})$ & 123.1 & 123.4 \\
\hline 18 & - & 135.8 & 132.6 \\
\hline 19 & $1.68(3 \mathrm{H}, \mathrm{s})$ & 25.8 & 25.7 \\
\hline 20 & $1.84(3 \mathrm{H}, \mathrm{s})$ & 18.2 & 18.1 \\
\hline 7-OMe & $3.78(3 \mathrm{H}, \mathrm{s})$ & 62.0 & 61.2 \\
\hline
\end{tabular}

* Sen et al., 1982 
Table 2.

\begin{tabular}{|c|c|c|c|c|}
\hline Position & $\delta \mathbf{H}$ & $\delta_{\mathrm{C}}$ & ${ }^{1} \mathrm{H}-{ }^{1} \mathrm{H}$ COSY & НМВС \\
\hline 1 & $13 . .35(1 \mathrm{H}, \mathrm{s}, \mathrm{OH})$ & 159.7 & - & C-1, C-2, C-9a \\
\hline 2 & - & 111.5 & - & - \\
\hline 3 & - & 163.5 & - & - \\
\hline 4 & $6.24(1 \mathrm{H}, \mathrm{s})$ & 88.8 & - & C-2, C-4a, C-9a \\
\hline $4 a$ & & 154.4 & - & - \\
\hline 5 & $6.74(1 \mathrm{H}, \mathrm{s})$ & 101.5 & - & $\mathrm{C}-7, \mathrm{C}-8 \mathrm{a}$ \\
\hline 6 & - & 155.6 & - & - \\
\hline 7 & - & 142.5 & - & - \\
\hline 8 & - & 137.0 & - & - \\
\hline $8 \mathrm{a}$ & - & 112.3 & - & - \\
\hline 9 & - & 181.9 & - & - \\
\hline $9 \mathrm{a}$ & - & 103.8 & - & - \\
\hline $10 \mathrm{a}$ & - & 155.2 & - & - \\
\hline 11 & $4.00(2 \mathrm{H}, \mathrm{d}, J=7.2 \mathrm{~Hz})$ & 31.2 & $\mathrm{H}-14$ & C-7, C-8 \\
\hline 12 & $5.18(1 \mathrm{H}, \mathrm{t}, J=7.2 \mathrm{~Hz})$ & 123.2 & $\mathrm{H}-11$ & - \\
\hline 13 & - & 131.7 & - & - \\
\hline 14 & $1.61(3 \mathrm{H}, \mathrm{s})$ & 29.7 & - & $\mathrm{C}-12, \mathrm{C}-13, \mathrm{C}-15$ \\
\hline 15 & $1.72(3 \mathrm{H}, \mathrm{s})$ & 17.8 & - & $\mathrm{C}-12, \mathrm{C}-13, \mathrm{C}-14$ \\
\hline 16 & $3.28(2 \mathrm{H}, \mathrm{d}, J=7.2 \mathrm{~Hz})$ & 21.3 & H-19 & $\begin{array}{c}\mathrm{C}-1, \mathrm{C}-2, \mathrm{C}-3 \mathrm{C}-17, \\
\mathrm{C}-18\end{array}$ \\
\hline 17 & $5.17(1 \mathrm{H}, \mathrm{t}, J=7.2 \mathrm{~Hz})$ & 122.3 & $\mathrm{H}-16$ & - \\
\hline 18 & - & 132.0 & - & - \\
\hline 19 & $1.62(3 \mathrm{H}, \mathrm{s})$ & 25.8 & - & $\mathrm{C}-17, \mathrm{C}-18, \mathrm{C}-20$ \\
\hline 20 & $1.75(3 \mathrm{H}, \mathrm{s})$ & 18.2 & - & C-17, C-18, C-19 \\
\hline 3-OMe & $3.73(3 \mathrm{H}, \mathrm{s})$ & 55.8 & - & $\mathrm{C}-3$ \\
\hline 7-OMe & $3.82(3 \mathrm{H}, \mathrm{s})$ & 62.0 & - & $\mathrm{C}-7$ \\
\hline
\end{tabular}

Table 3.

Ishigoru et al., 1992

\begin{tabular}{|c|c|c|c|}
\hline Position & $\delta \mathbf{H}$ & $* \delta \mathrm{C}$ & $\delta \mathrm{C}$ \\
\hline 1 & - & 161.6 & 161.4 \\
\hline 2 & - & 111.3 & 111.0 \\
\hline 3 & - & 163.4 & 163.2 \\
\hline 4 & $6.15(1 \mathrm{H}, \mathrm{s})$ & 93.0 & 92.9 \\
\hline $4 \mathrm{a}$ & - & 156.4 & 152.9 \\
\hline 5 & $6.60(1 \mathrm{H}, \mathrm{s})$ & 101.1 & 100.9 \\
\hline 6 & - & 154.3 & 153.9 \\
\hline 7 & - & 142.2 & 141.9 \\
\hline 8 & - & 129.6 & 129.4 \\
\hline $8 \mathrm{a}$ & - & 112.2 & 112.1 \\
\hline 9 & - & 183.7 & 183.4 \\
\hline $9 \mathrm{a}$ & - & 104.0 & 103.8 \\
\hline $10 \mathrm{a}$ & - & 154.6 & 156.1 \\
\hline 11 & $4.05(2 \mathrm{H}, \mathrm{d}, J=6.4 \mathrm{~Hz})$ & 25.3 & 26.6 \\
\hline 12 & $5.22(1 \mathrm{H}, \mathrm{t}, J=6.4 \mathrm{~Hz})$ & 113.0 & 111.0 \\
\hline 13 & - & 131.8 & 131.6 \\
\hline 14 & $1.80(3 \mathrm{H}, \mathrm{s})$ & 18.0 & 18.3 \\
\hline 15 & $1.63(3 \mathrm{H}, \mathrm{s})$ & 26.1 & 26.1 \\
\hline 16 & $3.23(2 \mathrm{H}, \mathrm{d}, \mathrm{J}=6.8 \mathrm{~Hz})$ & 22.3 & 22.2 \\
\hline 17 & $5.22(1 \mathrm{H}, \mathrm{t}, J=6.8 \mathrm{~Hz})$ & 124.9 & 123.9 \\
\hline 18 & - & 131.7 & 131.5 \\
\hline 19 & $1.63(3 \mathrm{H}, \mathrm{s})$ & 26.7 & 25.9 \\
\hline 20 & $1.75(3 \mathrm{H}, \mathrm{s})$ & 18.4 & 17.9 \\
\hline
\end{tabular}


Table 4.

\begin{tabular}{|c|c|c|c|}
\hline Position & $\boldsymbol{\delta H}$ & $* \delta \mathbf{C}$ & $\boldsymbol{\delta} \mathbf{C}$ \\
\hline 1 & $13.81(1 \mathrm{H}, \mathrm{s}, \mathrm{OH})$ & 161.7 & 161.6 \\
\hline 2 & - & 111.8 & 111.9 \\
\hline 3 & - & 163.1 & 162.9 \\
\hline 4 & $6.37(1 \mathrm{H}, \mathrm{s})$ & 93.1 & 93.1 \\
\hline $4 \mathrm{a}$ & - & 156.3 & 155.7 \\
\hline 5 & $6.80(1 \mathrm{H}, \mathrm{s})$ & 102.5 & 102.5 \\
\hline 6 & - & 157.7 & 156.3 \\
\hline 7 & - & 144.5 & 144.4 \\
\hline 8 & - & 140.0 & 140.0 \\
\hline $8 \mathrm{a}$ & - & 111.0 & 111.9 \\
\hline 9 & - & 182.8 & 182.8 \\
\hline $9 \mathrm{a}$ & - & 103.6 & 103.6 \\
\hline $10 \mathrm{a}$ & - & 155.7 & 157.5 \\
\hline 11 & $3.45(2 \mathrm{H}, \mathrm{m})$ & 23.2 & 23.2 \\
\hline 12 & $1.74(2 \mathrm{H}, \mathrm{m})$ & 45.7 & 45.6 \\
\hline 13 & - & 70.5 & 70.5 \\
\hline 14 & $1.30(3 \mathrm{H}, \mathrm{s})$ & - & 29.2 \\
\hline 15 & $1.30(3 \mathrm{H}, \mathrm{s})$ & - & 29.2 \\
\hline 16 & $3.33(2 \mathrm{H}, \mathrm{d}, J=7.2 \mathrm{~Hz})$ & 22.0 & 21.9 \\
\hline 17 & $5.26(1 \mathrm{H}, \mathrm{t}, J=7.2 \mathrm{~Hz})$ & 123.5 & 123.4 \\
\hline 18 & - & 131.3 & 131.3 \\
\hline 19 & $1.76(3 \mathrm{H}, \mathrm{s})$ & 17.9 & 17.9 \\
\hline 20 & $1.63(3 \mathrm{H}, \mathrm{s})$ & 25.9 & 25.9 \\
\hline $7-\mathrm{OMe}$ & $3.83(3 \mathrm{H}, \mathrm{s})$ & 61.5 & 61.6 \\
\hline
\end{tabular}

* Bennet, G.J. et al., 1993

Table 5.

\begin{tabular}{|c|c|c|c|c|}
\hline Position & $\delta \mathbf{H}$ & $\delta_{\mathrm{C}}$ & ${ }^{1} \mathrm{H}-{ }^{1} \mathrm{H}$ COSY & HMBC \\
\hline 1 & $12.34(1 \mathrm{H}, \mathrm{s}, \mathrm{OH})$ & 158.2 & - & C-2, C-9a, C-1 \\
\hline 2 & - & 109.6 & - & - \\
\hline 3 & - & 161.7 & - & - \\
\hline 4 & - & 105.9 & - & - \\
\hline $4 \mathrm{a}$ & - & 152.5 & - & - \\
\hline 5 & - & 135.8 & - & - \\
\hline 6 & $7.22(1 \mathrm{H}, \mathrm{d}, J=9.2 \mathrm{~Hz})$ & 123.0 & $\mathrm{H}-7$ & C-10a, C-8 \\
\hline 7 & $6.66(1 \mathrm{H}, \mathrm{d}, J=9.2 \mathrm{~Hz})$ & 109.8 & H-6 & $\mathrm{C}-8 \mathrm{a}, \mathrm{C}-5$ \\
\hline 8 & $11.26(1 \mathrm{H}, \mathrm{s}, \mathrm{OH})$ & 153.9 & - & C-7, C-8a, C-8 \\
\hline $8 \mathrm{a}$ & - & 107.2 & - & - \\
\hline 9 & - & 184.8 & - & - \\
\hline $9 \mathrm{a}$ & - & 102.3 & - & - \\
\hline $10 \mathrm{a}$ & - & 142.9 & - & - \\
\hline 11 & $3.45(2 \mathrm{H}, \mathrm{d}, J=8.2 \mathrm{~Hz})$ & 21.7 & - & $\begin{array}{c}\mathrm{C}-2, \mathrm{C}-12, \mathrm{C}-13, \mathrm{C}-1, \\
\mathrm{C}-3\end{array}$ \\
\hline 12 & $5.26(2 \mathrm{H}, \mathrm{m})$ & 121.1 & - & C-15, C-14 \\
\hline 13 & - & 136.4 & - & - \\
\hline 14 & $1.79(3 \mathrm{H}, \mathrm{s})$ & 26.0 & - & $\mathrm{C}-12, \mathrm{C}-13$ \\
\hline 15 & $1.86(3 \mathrm{H}, \mathrm{s})$ & 18.1 & - & C-12, C-13 \\
\hline 16 & $3.51(2 \mathrm{H}, \mathrm{d}, J=6.4 \mathrm{~Hz})$ & 22.1 & - & $\begin{array}{c}\mathrm{C}-4, \mathrm{C}-17, \mathrm{C}-18, \mathrm{C}-4 \mathrm{a}, \\
\mathrm{C}-3\end{array}$ \\
\hline 17 & $5.26(2 \mathrm{H}, \mathrm{m})$ & 121.9 & - & C-19, C-20 \\
\hline 18 & 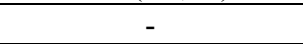 & 134.1 & - & - \\
\hline 19 & $1.86(3 \mathrm{H}, \mathrm{s})$ & 18.1 & - & C-17, C-18 \\
\hline 20 & $1.75(3 \mathrm{H}, \mathrm{s})$ & 25.8 & - & C-17, C-18 \\
\hline
\end{tabular}


Table 6.

\begin{tabular}{|c|c|c|c|c|}
\hline Position & $* \delta \mathbf{H}$ & $\delta \mathbf{H}$ & $* \delta \mathrm{C}$ & $\delta \mathrm{C}$ \\
\hline 2 & & - & 79.5 & 79.5 \\
\hline 3 & $\begin{array}{c}3.78(1 \mathrm{H}, \mathrm{dd}, \mathrm{J}=5.5 \\
7.3 \mathrm{~Hz})\end{array}$ & $3.74(1 \mathrm{H}, \mathrm{dd}, J=5.5,7.3 \mathrm{~Hz})$ & 69.6 & 69.6 \\
\hline 4 & $\begin{array}{c}2.58(1 \mathrm{H}, \mathrm{dd}, \mathrm{J}=7.3 \\
17.3 \mathrm{~Hz}) \\
2.92(1 \mathrm{H}, \mathrm{dd}, \mathrm{J}=5.5,17.3 \mathrm{~Hz})\end{array}$ & $\begin{array}{l}2.52(1 \mathrm{H}, \mathrm{dd}, J=7.3,17.4 \mathrm{~Hz}) \\
2.88(1 \mathrm{H}, \mathrm{dd}, J=5.5,17.4 \mathrm{~Hz})\end{array}$ & 27.1 & 27.0 \\
\hline $4 \mathrm{a}$ & & - & 105.4 & 105.4 \\
\hline 5 & & - & 156.2 & 156.1 \\
\hline $5 \mathrm{a}$ & & - & 107.6 & 107.5 \\
\hline 6 & & - & 178.9 & 178.9 \\
\hline $6 a$ & & - & 114.9 & 114.9 \\
\hline 7 & & - & 138.3 & 138.3 \\
\hline 8 & & - & 144.9 & 144.8 \\
\hline 9 & & - & 155.7 & 155.7 \\
\hline 10 & $6.66(1 \mathrm{H}, \mathrm{s})$ & $6.62(1 \mathrm{H}, \mathrm{s})$ & 102.3 & 102.3 \\
\hline $10 \mathrm{a}$ & & - & 156.8 & 156.8 \\
\hline $11 \mathrm{a}$ & & - & 158.4 & 158.3 \\
\hline 12 & $6.32(1 \mathrm{H}, \mathrm{s})$ & $6.30(1 \mathrm{H}, \mathrm{s})$ & 94.4 & 94.4 \\
\hline $12 \mathrm{a}$ & & - & 162.2 & 162.2 \\
\hline 1 ' & $\begin{array}{l}4.03(1 \mathrm{H}, \mathrm{dd}, J=7.0,14.0 \mathrm{~Hz}) \\
4.07(1 \mathrm{H}, \mathrm{dd}, J=7.0,14.0 \mathrm{~Hz})\end{array}$ & $4.00(2 \mathrm{H}$, brt, $J=7.3 \mathrm{~Hz})$ & 27.1 & 27.0 \\
\hline 2 ' & $5.30(1 \mathrm{H}, \mathrm{dd}, J=1.5,7.0 \mathrm{~Hz})$ & $5.24(1 \mathrm{H}$, brt, $J=7.3 \mathrm{~Hz})$ & 125.7 & 125.7 \\
\hline $3{ }^{\prime}$ & & - & 131.4 & 131.4 \\
\hline $4^{\prime}$ & $1.82(3 \mathrm{H}, \mathrm{s})$ & $1.77(3 \mathrm{H}, \mathrm{s})$ & 18.4 & 18.3 \\
\hline 5, & $1.67(3 \mathrm{H}, \mathrm{s})$ & $1.62(3 \mathrm{H}, \mathrm{s})$ & 26.0 & 25.9 \\
\hline 2-Me & $\begin{array}{l}1.34(3 \mathrm{H}, \mathrm{s}) \\
1.46(3 \mathrm{H}, \mathrm{s})\end{array}$ & $\begin{array}{l}1.30(3 \mathrm{H}, \mathrm{s}) \\
1.41(3 \mathrm{H}, \mathrm{s})\end{array}$ & $\begin{array}{l}20.7 \\
25.6\end{array}$ & $\begin{array}{l}20.6 \\
25.6\end{array}$ \\
\hline $8-\mathrm{OMe}$ & $3.75(3 \mathrm{H}, \mathrm{s})$ & $3.70(3 \mathrm{H}, \mathrm{s})$ & 61.3 & 61.3 \\
\hline
\end{tabular}

*Chairungsrilerd et al., 1996

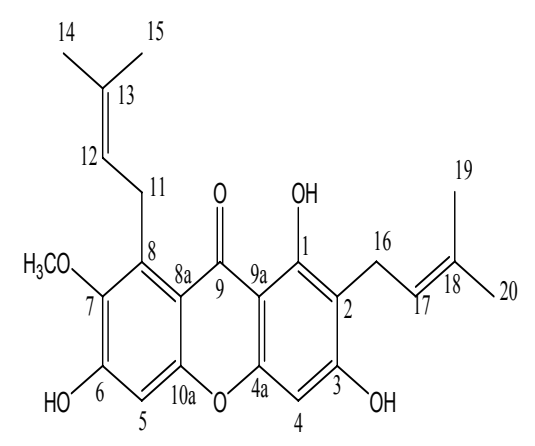

Figure 1.

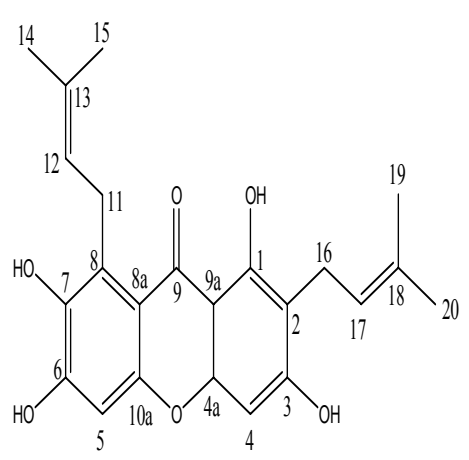

Figure 2. 


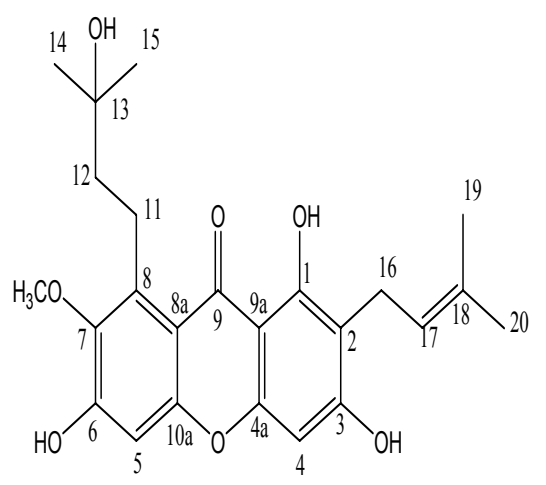

Figure 3.

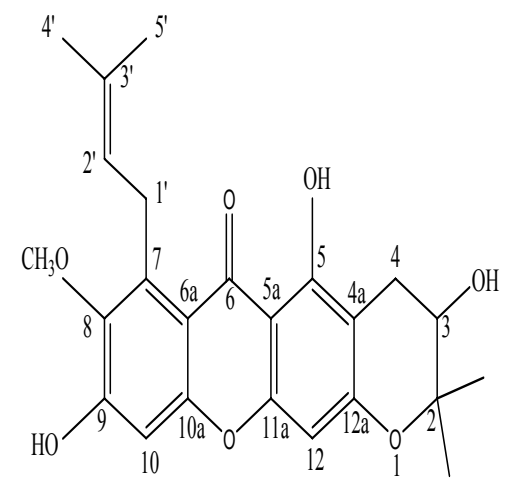

Figure 4.

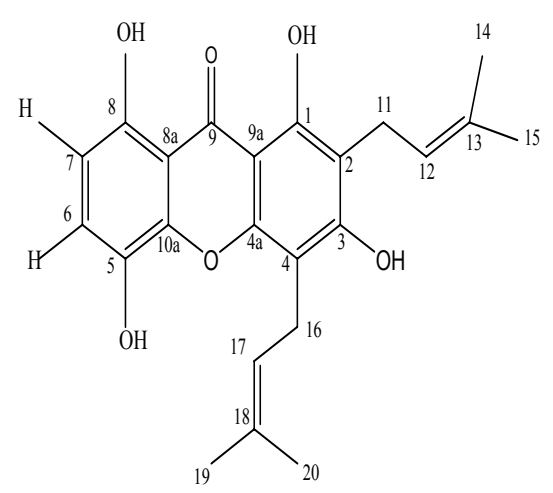

Figure 5. 


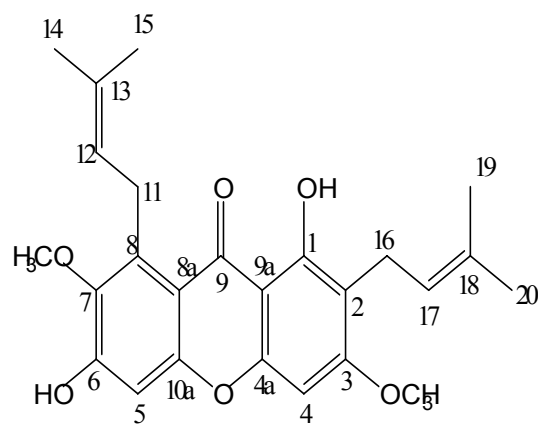

Figure 6. 